\title{
Pengaruh Faktor Kepribadian Dan Lingkungan Keluarga Terhadap Minat Berwirausaha (Studi Kasus Kelompok Pemuda Tani Desa Makmur Okura Rumbai Pesisir)
}

\author{
RITA WIYATI; SRI MARYANTI; M.THAMRIN \\ Universitas Lancang Kuning \\ Jln. Yos Sudarso Km 08 Rumbai Telp. (0761) 52581 Fax. (0761) 52581 \\ E-mail : ritawiyati@ymail.com
}

\begin{abstract}
Being an entrepreneur, working alone, managing, managing, and being responsible for the business, offers great personal challenges because individuals work with others, prefer to be employees, and work for others. Milineal era is now the time for youth to have creative and innovative thinking, with this background it is necessary to conduct a study of the influence of personality factors and family environmental factors on entrepreneurial interest in the farmer youth group Makmur Okura Village, Rumbai Coastal District. This study aims to look at the influence of personality factors and family factors on entrepreneurial interest, both partially and simultaneously. The population in this study were all members of the youth farmer groups in Makmur Okura Village, Rumbai Pesisir sub-district. As for the data collection techniques with questionnaires, documentation, interviews. The analytical method used is multiple linear regression. Based on the results of the study most of the members of the farmer group of high school and vocational students. The results showed that personality factors, family factors together (simultaneously) have an influence on entrepreneurial interest, while partially there is no influence of personality factors on entrepreneurial interest as well as for family factors no effect on entrepreneurial interest, there is a correlation between personality factors, family factors on entrepreneurial interest that is equal to $51.0 \%$. R square of 0.260 which means that the independent variables (personality and family) have an effect of $26 \%$ on entrepreneurial interest, and the remaining $74 \%$ are influenced by other factors.
\end{abstract}

Keywords: Entrepreneurship, Personality factors, Family factors

Kemajuan tehnologi dan ilmu pengetahuan memiliki andil dalam mendorong praktik praktik kewirausahaan yang mampu menciptakan berbagai macam penemuan produk dan jasa baru. Dewasa ini banyak orang yang belum mendapatkan pekerjaan untuk mencukupi kebutuhan hidup. Ada beberapa hal yang melatarbelakangi hal tersebut, diantaranya minimnya pendidikan, serta kurang adanya perhatian dari pemerintah untuk mendapatkan lapangan pekerjaan.

Berdasarkan data dan informasi yang disampaikan oleh tribun pada tanggal 24 bulan juli 2018, bahwa Hipmi (Himpunan Pengusaha Muda Indonesia ) di Riau telah terbentuk 1600 pengusaha pemula binaan. Hal ini menunjukkan antusias para kawula muda yang ada dikota pekanbaru maupun kota kabupaten lainnya yang berada diwilayah propinsi Riau. Diantaranya pengusaha pemula tersebut sudah memiliki usaha dan ingin mengembangkan usaha yang telah dijalananinya.

$\begin{array}{ccc}2 \text { Berdasarkan } & \text { survey dilapangan } \\ \text { diDesa } & \text { Makmur } & \text { Okura } \\ \text { kecamatan }\end{array}$
Rumbai Pesisir terdapat sekelompok pemuda desa tersebut yang berkeinginan untuk memanfaatkan lahan pekarangan seorang warga dan dengan anggota pemuda serta mahasiswa yang sedang kuliah di salah satu perguruan tinggi swasta dikota Pekanbaru, kelompok pemuda tersebut memiliki bentuk organisasi namanya Kelompok Pemuda Tani (KPT), dimana mereka memiliki ide dan tekad untuk menjalankan suatu usaha 
dengan memanfaatkan lahan yang ada untuk usaha budidaya Jamur Tiram Putih. Dari hasil wawancara pemuda yang berhasil ditemui mengatakan bahwa usaha yang dijalankan bersama kelompoknya hanyalah untuk batu loncatan saja menjelang dapat pekerjaan yang lain, disisi lain beberapa pemuda yang lain yang tergabung dalam kelompok pemuda tani tersebut sangatlah bercita cita bahwa usaha yang dijalaninya berharap dapat berkembang dan maju karena faktor kondisi keluarga yang dari keluarga sederhana. Dilain waktu tim peneliti melakukan survey kembali dengan mewawancarai anggota kelompok pemuda tani yang kuliah sambil menjalankan kegiatan budidaya jamur tiram ini, dari hasil wawancara bahwa pemuda tersebut semangat dalam menjalankan bisnisnya dan bercita cita dalam budidaya jamur tiram putih ini juga dapat mengolah hasil budidaya jamurnya memiliki produk turunan dan bisa dikenal orang banyak sampai keluar daerah. Dari Survey tersebut dapat dikatakan bahwa faktor kepribadian, keluarga sangatlah berperan penting sesorang dalam membuat keputusan untuk menggeluti sebuah bidang usaha.

Dalam menumbuhkan minat berwirausaha, salah satu faktor yang mendorong keberhasilan usaha adalah lingkungan keluarga, namun terdapat hal yang tidak kalah penting dalam menumbuhkan minat seseorang untuk berwirausaha yaitukepribadian. Secara umum kepribadian (personality) merupakan suatu pola watak yang relatif permanen dan sebuah karakter unik yang memebrikan konsistensi sekaligus individualis bagi perilaku seseorang.

Selain kepribadian faktor lain yang diduga mempengaruhi minat berwirausaha adalah lingkungan keluarga. Orang tua bertanggung jawab memelihara, merawat, melindungi, dan mendidik anak agar tumbuh dan berkembang dengan baik. Lingkungan keluarga adalah kelompok masyarakat terkecil yang terdiri dari ayah, ibu, anak, dan anggota keluarga yang lain.
Keluarga merupakan peletak dasar bagi pertumbuhan dan perkembangan anak, disinilah yang memberikan pengaruh awal terbentuknya kepribadian. Dukungan dari keluarga dapat menumbuhkan kepercayaan diri dalam diri seseorang sehingga dapat mendorong dan menumbuhkan minat untuk berwirausaha. Dari uraian diatas, dipandang perlu untuk dilakukan pengujian pengaruh faktor kepribadian, faktor keluarga terhadap minat berwirausaha.

Wirausaha adalah seseorang yang bebas dan memiliki kemampuan untuk hidup mandiri dalam menjalankan kegiatan usahanya atau bisnisnya atau hidupnya. Ia bebas merancang, menentukan mengelola, mengendalikan semua usahanya Aima dkk $(2015 ; 6)$.

Menurut Dharmawati (2016;13) kewirausahaan merupakan sikap mental dan sifat jiwa yang selalu aktif dalam berusaha untuk memajukan karya baktinya dalam rangka upaya meningkatkan pendapatan di dalam kegiatan usahanya. Selain itu, kewirausahaan adalah kemampuan kreatif dan inovatif yang dijadikan dasar, kiat, dan sumber daya untuk mencari peluang menuju sukses.

Menurut Ducker Kasmir $(2014 ; 20)$ bahwa kewirausahaan merupakan kemampuan dalam menciptakan sesuatu yang baru dan berbeda. Pengertian ini mengandung maksud bahwa seorang wirausahawan adalah orang yang memiliki kemampuan untuk menciptakan sesuatu yang baru, berbeda dari yang lain. Atau mampu menciptakan sesuatu yang berbeda dengan yang sudah ada sebelumnya.

Menurut Alma (2006;1) semakin maju suatu negara semakin banyak orang yang terdidik, dan banyak pula orang menganggur, maka semakin dirasakan pentingnya dunia wirausaha. Pembangunan akan lebih berhasil jika ditunjang oleh wirausahawan yang dapat membuka lapangan kerja karena kemampuan permerintah sangat terbatas. 
Pemerintah tisdak akan mampu menggarap semua aspek pembangunan karena sangat banyak membutuhkan anggaran belanja, personalia, dan pengawasan.

Oleh sebab itu, wirausaha merupakan potensi poembangunan, baik dalam jumlah maupun dalam mutu wirausaha itu sendiri. Sekarang ini kita dan mutunya belum bisa dikatakan benar, sehingga persoalan pembangunan wirausaha Indonesia merupakan persoalan mendesak bagi suksesnya pembangunan. Jika kita perhatikan manfaat adanya wirausaha banyak sekali.

Menurut Kasmir (2014;23) pengertian etika adalah tata cara berhubungan dengan manusia lainnya. Tata cara pada masing - masing masyarakat tidaklah sama atau beragam bentuk. Hal ini disebabkan beragamnya budaya kehidupan masyarakat yang berasal dari berbagai wilayah. Tata cara ini diperlukan dalam berbagai sendi kehidupan manusia agar terbina hubungan yang harmonis, saling menghargai satu sama lainnya.

Menurut Suryana (2008) minat wirausaha dipengaruhi oleh beberapa faktor, yaitu faktor internal dan faktor eksternal dan dapat diuraikan sebagai berikut (Yang termasuk Faktor Internal antara lain : kepribadian, persepsi, motivasi, pembelajaran atau sikap) dan yang termasuk faktor Eksternal antara lain: keluarga, teman, tetangga, dan lain lain).

Menurut penelitian yang dilakukan oleh Sri Maryanti, Rita Wiyati dan M. Thamrin (2017), bahwa Universitas Lancang Kuning merupakan salah satu universitas yang ikut menerapkan kurikulum yang didalamnya ada mata kuliah kewirausahaan, dari sembilan fakultas terdiri dari sembilan belas prodi dan dari sembilan belas prodi tersebut hanya delapan belas prodi yang menerapkan atau menyajikan mata kuliah kewirausahaan, hal ini merupakan daya tarik tersendiri untuk menghasilkan mahasiswa yang memiliki jiwa kewirausahaan. Kewirausahaan hanya sebatas teori saja seperti mencatat lalu dilakukan ujian semester dan jika pun ada beberapa fakultas yang menerapkan bentuk praktek kewirausahaan kepada mahasiswa seperti mahasiswa menjual kue-kue yang mereka beli/membuat sendiri kepada teman-teman maupun dosen yang ada hanya sebatas untuk pemenuhan tugas yang diberikan oleh dosen pengasuh matakuliah kewirausahaan dan harapan nya hanya ingin mendapatkan nilai bagus saja, tanpa dibarengi dengan memaknai apa tujuan mata kuliah kewirausahaan.

$$
\text { Hasil penelitian Desi Yusrita }
$$

(2018: 89) yang dilaksanakan di Universitas Lancang Kuning Pekanbaru menunjukkan bahwa Harga Diri, Tantangan Pribadi, Keinginan Menjadi Bos, Inovasi, Kepemimpinan, Fleksibilitas, Keuangan, dan Lingkungan secara bersama - sama (simultan) mempunyai pengaruh yang signifikan terhadap Minat Wirausaha.

$$
\text { Menurut peraturan menteri }
$$
pertanian nomor: 273/Kpts/OT.160/4/ 2007 kelompok tani adalah kumpulan petani adalah kumuplan petani/peternak/ pekebun yang dibentuk atas dasar kesamaan kepentingan, kesamaan kondisi lingkungan(sosial, ekonomi, sumberdaya) dan keakraban untuk meningkatkan dan mengebangkan usaha anggota. Kelompok tani juga dapat diartikan organisasi non formal dipedesaan yang ditumbuhkembangkan dari, oleh dan untuk petani. Umunya kelompok tani dibentuk atas dasar kesamaan tujuan, kesamaan kepentingan dan kesamaan kondisi dalam suatu lingkungan petani. dengan dibentuknya kelompok tani mempermudah untuk penyampaian materi penyuluhan berupa pembinaan dalam memberdayakan petani agar memiliki kemandirian, bisa menerapkan inovasi ,dan mampu menganalisa usahatani, sehingga petani dan keluarganya bisa memperoleh pendapatan dan kesejahteraan yang meningkat dan layak. Adanya kelompok tani bertujuan untuk memperkuat kerjasama antar petani/ 
nelayan di dalam lingkungan organisasi kelompok tani ataupun pihak lain diluar kelompok tani. dengan kerjasama yang dibentuk diharapkan kelompok tani bisa lebih efisien serta lebih mampu menghadapi tantangan, hambatan, gangguan ataupun ancaman dalam usaha tani. Ciri ciri dikatakan sebagi kelompok tani, antara lain : (1).Biasanya kelompok tani saling mengenal, saling akrab dan saling percaya antar sesama anggota dan pengurus. (2). Mempunyai tujuan, pandangan dan kepentingan yang sama dalam usaha tani. samanya tradisi dalam lingkungan, hampara, jenis usaha yang dilakukan, dan status ekonomi, social, bahasa maupun pendidikan. (3) Memiliki tanggung jawab setiap anggota dan pengurus.

Kelompok tani minimal mempunyai kepengurusan dimulai dari ketua, sekretaris dan bendahara kelompok yang dipilih oleh masyarakat tani. kelompok tani harus diketahui dan disahkan oleh pihak pemerintah setempat baik tingkat desa atau kelurahan setempat.Dalam aturan baru para pengurus kelompok tani wajib berbadan hukum dan terdaftar di Kementrian Hukum dan HAM.

Kewirausahaan (entrepreneurship) adalah proses penciptaan sesuatu yang baru pada nilai menggunakan waktu dan upaya yang diperlukan, menanggung risiko keuangan, fisik, serta risiko sosial yang mengiringi, menerima imbalan moneter yang dihasilkan, serta kepuasan dan kebebasan pribadi. Kewirausahaan penting bagi suatu negara sebagai pendukung kenaikan taraf perekonomian, para wirausaha dapat menciptakan industriindustri kreatif baru yang menstimulasi minat calon-calon wirausaha lainnya untuk bergabung bahkan mampu menyediakan lapangan pekerjaan baru bagi orang lain dan mampu menyerap tenaga kerja lebih banyak dengan tujuan mengurangi masalah pengangguran.

Beberapa faktor penentu yang berharga dalam mempertahankan jiwa sekaligus kemampuan kewirausahaan adalah sikap positif, tekad, pengalaman, ketekunan dan kerja keras. Beberapa faktor yang dikemukakan Meredith tersebut cenderung bersifat internal. Fungsinya ialah menjadi prasyarat bagi seseorang yang mengembangkan kewirausahaan. Menurut Siswadi (2013), Adapun faktor internal dan faktor ekternal dalam kewirausahaan sebagi berikut ini:

Menurut Siswadi (2013) dalam Made (2016) faktor internal dalam kewirausahaan meliputi Motivasi Pribadi dan Kepribadian.

\section{Motivasi Pribadi}

Supardi dan Anwar dalam penelitian Siswadi (2013) mengatakan motivasi adalah keadaan dalam pribadi seseorang yang mendorong keinginan individu untuk melakukan kegiatankegiatan tertentu guna mencapai tujuan. Motivasi yang ada pada sescorang akan mewujudkan suatu perilaku yang diarahkan pada tujuan mencapai sasaran kepuasan. Motivasi merupakan hal yang melatar belakangi individu berbuat untuk mencapai tujuan tertentu.

\section{Kepribadian}

Law dan Hung dalam penelitian Siswadi (2013) upaya memahami karakteristik wirausaha dengan menggunakan aspek kepribadian menghasilkan karakteristik sebagai berikut: wirausaha cenderung pengambil risiko, berorientasi mencapai hasil, komitmen, toleransi terhadap ketidakpastian dan mempunyai visi.

Menurut Siswadi (2013) dalam Made (2016) Faktor eksternal meliputi Lingkungan Keluarga dan Lingkungan Sosial :

\section{Lingkungan keluarga}

Lingkungan keluarga adalah kelompok masyarakat yang terkecil yang terdiri dari ayah, ibu, dan anak,dan anggota keluarga yang lain. Keluarga merupakan peletak dasar bagi pertumbuhan dan perkembangan anak, 
disinilah yang memberikan pengaruh awal terhadap terbentuknya kepribadian.

\section{Lingkungan sosial}

Lingkungan sosial merupakan hubungan interaksi antara masyarakat dengan lingkungan. Interaksi ini terjadi bila di antara individu yang satu dengan yang lain mempunyai hubungan yang erat dan saling mengenal dengan baik, misalnya keluarga.

\section{METODE}

Populasi dalam penelitian ini adalah seluruh anggota kelompok pemuda tani desa Makmur Okura yang berjumlah 30 orang , dan karena sedikitnya populasi maka dalam penelitian ini seluruh populasi dijadikan sampel.

Variabel penelitian ini adalah sebagai variabel bebas Faktor Kepribadian (X1), Faktor Lingkungan Keluarga (X2) dan sebagai variabel terikat adalah Minat Berwirausaha (Y).

Pengumpulan data dalam penelitian ini menggunakan kuisioner . Kuisioner merupakan tehnik pengumpulan data dimana partisipan/ responden mengisi pertanyaan atau pernyataan kemudian setelah diisi dengan lengkap mengembalikan kepada peneliti.

Analisis linear berganda digunakan untuk mengukur pengaruh lebih antara lebih dari satu variabel bebas terhadap variable terikat dan dapat dinyatakan dengan

$$
\mathbf{Y}=\mathbf{a}+\mathbf{b}_{1} \mathbf{X}_{1}+\mathbf{b}_{2} \mathbf{X}_{2}+\mathbf{e}
$$

Analisis korelasi yang digunakan dalam penelitian ini adalah korelasi ganda dengan alasan karena korelasi ganda merupakan angka yang menunjukkan arah dan kuatnya hubungan antara dua variabel secara bersama - sama atau lebih dengan variabel lain.

Koefisien determinasi $\left(\mathrm{R}^{2}\right)$ pada intinya mengukur seberapa jauh kemampuan model dalam menerangkan variasi variabel terikat Kuncoro $(2009 ; 240)$.
Koefisien determinasi $\left(\mathrm{R}^{2}\right)$ dalam regresi berganda digunakan untuk mengetahui persentase pengaruh variabel independen secara serentak terhadap variabel dependen. Koefisien ini menunjukkan seberapa besar persentase variabel-variabel independen yang digunakan dalam model mampu menjelaskan variasi variabel dependen. $\mathrm{R}^{2}$ sama dengan 0 , maka tidak ada sedikitpun persentase pengaruh yang diberikan variabel independen terhadap variabel dependen atau variasi variabel independen yang diguakan dalam model tidak menjelaskan sedikitpun variasi variabel dependen. Jika $\mathrm{R}^{2}$ sama dengan 1, maka persentase pengaruh yang diberikan variabel independen terhadap variabel dependen adalah sempurna, atau variasi variabel independen yang digunakan dalam model menjelaskan $100 \%$ variasi variabel dependen.

\section{Uji Parsial (Uji t)}

Uji parsial atau uji t untuk menguji bagaimana pengaruh masing-masing variabel bebas secara sendiri-sendiri terhadap variabel terikat. Uji ini dapat dilakukan dengan membandingkan t hitung dengan $\mathrm{t}$ tabel atau dengan melihat kolom signifikan pada masing-masing $t$ hitung.

\section{Uji Simultan (Uji F)}

Uji ini dapat dilakukan dengan membandingkan antara $\mathrm{F}$ hitung dan $\mathrm{F}$ tabel. Apabila $\mathrm{F}$ hitung < F tabel, maka variabel bebas secara serentak tidak berpengaruh terhadap variabel terikat. Sebaliknya, apabila F hitung > F tabel maka variabel bebas secara bersama-sama berpengaruh terhadap variabel terikat.

\section{HASIL}

Untuk melakukan uji hipotesis penelitian, maka lebih dahulu kita harus mengetahui dasar pengambilan keputusan dalam uji t parsial. Salah satunya berdasarkan nilai signifikansi (sig.) Jika nilai signifikansi (Sig.) < probabilitas 0.05 maka ada pengaruh variabel bebas (x) terhadap variabel terikat $(\mathrm{Y})$ atau hipotesis 
diterima. Dan jika nilai signifikansi (Sig.) > probabilitas 0,05 maka tidak ada pengaruh variabel bebas $(\mathrm{X})$ terhadap variabel terikat (Y) atau hipotesis ditolak. Atau pengujian berdasarkan perbandingan antara nilai $t$ tabel dan $t$ hitung.. Jika nilai t hitung lebih besar dari $t$ tabel maka ada pengaruh variabel bebas dan (X) terhadap variabel terikat $(\mathrm{Y})$ ata hipotesis diterima. Jika nilai t hitung lebih lecil dari t tabel maka tidak ada pengaruh variabel bebas $(\mathrm{X})$ terhadap variabel terikat (Y) atau hipotesis ditolak.

Tabel 1. :Hasil Uji t(Parsial)

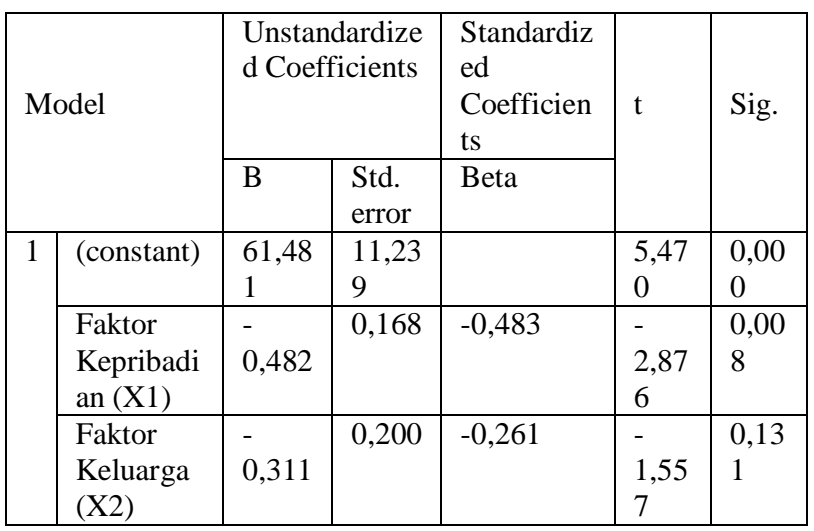

Dari tabel di atas dapat dijelaskan bahwa hasil uji t untuk faktor kepribadian bernilai negatif sebesar $-2,876$, atau $t$ hitung lebih kecil dari t tabel $(2,052)$, maka Ho diterima Ha ditolak, artinya, bahwa faktor kepribadian secara parsial tidak berpengaruh terhadap minat berwirausaha. Dan untuk faktor keluarga bernilai negarif juga sebesar -1,557 makan Ho diterima dan Ha ditolak yang artinya bahwa faktor keluarga tidak berpengaruh terhadap minat berwirausaha

Uji ini digunakan untuk menguji kooefisiensi regresi secara keseluruhan dan untuk mengetahui pengaruh antara variabel independen secara bersama sama dengan variabel dependen . Pengujian hipotesis akan menggunakan tingkat signifikasi sebesar 5\% atau 0,05.. Berikut ini tabel hasil uji F:
Tabel. 2. : Hasil uji F (Simultan)

\begin{tabular}{|l|l|l|l|l|l|l|}
\hline Model & & $\begin{array}{l}\text { Sum Of } \\
\text { Squares }\end{array}$ & df & $\begin{array}{l}\text { Mean } \\
\text { Square }\end{array}$ & F & Sig. \\
\hline \multirow{4}{*}{1} & Regression & 31,676 & 2 & 15,838 & 4,741 & .017 \\
\cline { 2 - 7 } & Residual & 90,191 & 27 & 3,340 & & \\
\cline { 2 - 7 } & Total & 121,867 & 29 & & & \\
\hline
\end{tabular}

Dari tabel diatas dapat dijelaskan bahwa menunjukkan nilai Fhitung sebesar 4,741 dengan taraf signifikan 0.05 dan $\mathrm{F}$ tabel sebesar 4,21 . atau $F$ hitung $>F$ tabel atau $(4,741>4,21)$ artinya Ho ditolak dan Ha diterima, dengan kata lain bahwa secara simultan atau bersama sama faktor kepribadian dan faktor keluarga berpengaruh terhadap minat berwirausaha.

Tabel 3. : Uji Korelasi dan Determinasi

Model Summary
\begin{tabular}{|l|l|l|l|l|l|}
\hline $\begin{array}{l}\text { Mod } \\
\text { el }\end{array}$ & R & $\begin{array}{l}\text { R } \\
\text { Squa } \\
\text { re }\end{array}$ & $\begin{array}{l}\text { Adjust } \\
\text { ed R } \\
\text { Square }\end{array}$ & $\begin{array}{l}\text { Std.Err } \\
\text { or of } \\
\text { the } \\
\text { Estima } \\
\text { te }\end{array}$ & $\begin{array}{l}\text { Durbi } \\
\text { - } \\
\text { Watso } \\
\text { n }\end{array}$ \\
\hline 1 & $\begin{array}{l}.51 \\
0^{\mathrm{a}}\end{array}$ & 0,260 & 0,205 & 1,828 & 2,179 \\
\hline
\end{tabular}

Analisis korelasi digunakan untuk mengukur besarnya hubungan antara dua variabel atau lebih. Analisis korelasi digunakan untuk mengetahui kekuatan hubungan anatara korelasi kedua variabel dan ukuran yang dipakai untuk menentukan derajat atau kekuatan hubungan korelasi tersebut dengan menggunakan koeefiisen Pearson Correction Product Moment.Dalam penelitian ini nilai koeefiisen korelasi (R) sebesar 0,510. Hal ini menunjukkan bahwa terdapat korelasi antara faktor kepribadian, faktor keluarga terhadap minat berwirausaha yaitu sebesar $51,0 \%$.

Koefisien determinasi digunakan untuk mengetahui besarnya tingkat pengaruh atau tinggi rendahnya pengaruh antara faktor kepribadian, faktor keluarga terhadap minat berwirausaha. Dari hasil perhitungan SPSS diatas ditunjukkan bahwa R square sebesar 0,260 yang artinya bahwa variabel independen (kepribadian 
dan keluarga) memberikan pengaruh sebesar $26 \%$ terhadap minat berwirausaha, dan sisanya $74 \%$ dipengaruhi oleh faktor lain.

\section{PEMBAHASAN}

Penelitian ini bertujuan untuk mengetahui pengaruh faktor kepribadian, faktor keluarga terhadap minat berwirausaha pada kelompok pemuda tani cendawan House Desa Makmur. Dari hasil penelitian diatas bahwa diuji secara parsial hasilnya menunjukkan tidak ada pengaruh faktor kepribadian terhadap minat berwirausaha begitu juga faktor keluarga tidak ada pengaruh terhadap minat berwirausaha sedangkan diuji secara simultan berpengaruh antara faktor kepribadian , faktor keluarga terhadap minat berwirausaha. Hal ini berbeda dengan penelitian Retno Endah dkk, dalam prosiding seminar nasional dan call for paper Ekonomi dan Bisnis, Jember 28 0ktober 2017, bahwa hasil penelitian endah dkk, faktor keluarga , pendidikan kewirausahaan, pendapatan, media sosial berpengaruh signifikan terhadap minat berwiarusaha pada pemuda yang aktif kuliah diperguruan tinggi swasta. Penelitian lain menunjukkan bahwa pengaruh pembelajaran kewirausahaan terhadap minat berwirausaha oleh cristianingrum dkk pada Integrated Journal Of Businness and Economic (IJBE) vol 1. No 1. 2017, bahwa pembelajaran kewirausahaan mampu menarik minat mahasiswa berwirausaha dan mahasiswa mampu diajak dan diarahkan membuka wawasan tentang berwirausaha.

Dari hasil penelitian yang kami lakukan diatas tentang pengaruh faktor kepribadian, faktor keluarga terhadap minat berwirausaha di kelompok tani desa Makmur okura Rumbai Pesisir, disini dapat disampaikan bahwa karena sebagaian besar anggotanya pelajar mulai dari SMP sampai dengan jenjang SMA dan Jenjang status mahasiswa yang sedang aktif kuliah, tentunya perhatian atau fokus untuk berbisnis belumlah maksimal dilaksanakan karena setiap harinya fokus untuk belajar sampai dengan jam 3 sore, belum lagi jika ada pekerjaan sekolah yang harus dikerjakan dirumah sehingga untuk berwirausaha belum terpikirkan kearah sana. Disamping anggota kelompok tani tersebut juga biaya hidupnya masih banyak menjadi tanggungan keluarganya.Sehingga hasil penelitian ini terdukung oleh kenyataan yang ada, bahwa kategori masih pelajar tentunya keinginan waktu untuk bermain masih banyak, rasa tanggung jawab terhadap pekerjaan masih minim, disamping kelompok tani ini juga belum begitu merasakan dari adanya manfaatnya berwirausaha, berwirausaha yang berhasil dan sukses, anggota kelompok tani tersebut belum memikirkannya.

\section{SIMPULAN}

Dari hasil penelitian menunjukkan bahwa faktor kepribadian, faktor keluaraga secara bersama sama (simultan) mempunyai pengaruh terhadap minat berwirausaha, hal ini ditunjukkan dengan uji $\mathrm{F}$ hitung sebesar 4,741, sedangkan $\mathrm{F}$ tabel 4,21, karena $\mathrm{F}$ hitung > dari F tabel, maka Ho ditolak, Ha diterima. Sedangkan secara parsial tidak ada pengaruh faktor kepribadian terhadap Minat berwirausaha, hal ini ditunjukan dari hasil uji $\mathrm{t}$ tabel $>\mathrm{t}$ hitung, dimana nilai $\mathrm{t}$ tabel $(2,052)>\mathrm{t}$ hitung $(-2,876)$, begitu juga untuk faktor keluarga tidak berpengaruh terhadap minat berwirausaha ditunjukkan oleh hasil uji t tabel $>\mathrm{t}$ hitung, dimana nilai $\mathrm{t}$ tabel $(2,052)>\mathrm{t}$ hitung (1,557) dan nilai koeefiisen korelasi (R) sebesar 0,510. Hal ini menunjukkan bahwa terdapat korelasi antara faktor kepribadian, faktor keluarga terhadap minat berwirausaha yaitu sebesar 51,0 \%. R square sebesar 0,260 yang artinya bahwa variabel independen (kepribadian dan keluarga) memberikan pengaruh sebesar 26 $\%$ terhadap minat berwirausaha, dan sisanya $74 \%$ dipengaruhi oleh faktor lain.

Sebaiknya anggota kelompok tani desa makmur Okura, para anggotanya sebaiknya untuk kategori umurnya yang sudah lebih dewasa dan sudah mulai mampu berpikir dalam berkreasi, berinovasi, dalam berwirausaha. Disamping itu sebaiknya bukan pelajar agar dalam 
pengembangkan usaha lebih fokus kebidang usaha yang digelutinya.

\section{DAFTAR RUJUKAN}

Alma, Buchari, 2006, Kewirausahaan untuk Mahasiswa dan Umum, Alfabeta Bandung

Aima, Havidz., dkk 2015, Entrepreneurship \& Peluang Usaha, In Media

Bhandari , Narendra C. 2006. Intention For Entrepreneurship Among Student In India Journal Entrepreneurship 15(2), pp: 169-171

Christianingsrum dkk, pengaruh pembelajaran kewirausahaan terhadap Minat berwirausaha, IJBE vol 1, No.1, 2017

D. Made Dharmawati, Kewirausahaan, Rajawali press, agustus 2016

Daryanto, Cahyono, Aris Dwi, 2013, Kewirausahaan

Fahmi , Irham, 2014, Kewirausahaan Teori, Kasus dan Solusi, Alfabeta: Bandung

Kasmir, 2014, Kewirausahaan, PT. Rajagrafindo Persada: Jakarta

Maryanti, Wiyati, Thamrin, Startegi Menumbuhkan jiwa Entrepreneur Mahasiswa Di Universitas Lancang Kuning, Vol 9 No.3

Nitisemito Mulyadi, 2009, Kewirausahaan \& Manajemen usaha Kecil, Alfabeta, Bandung

Retno Endah dkk, Minat Berwirausaha pada Mahasiswa Perguruan Tinggi Swasta di Jember, prosiding seminar nasional dan call for paper Ekonomi dan Bisnis, Jember 28 0ktober 2017
Sadeli, Model Penciptaan Usaha Mandiri, Jurnal Administrasi Bisnis, Vol 8 No 2, 2011. 